\section{Early development of corn seedlings primed with synthetic tenorite nanofertilizer}

\author{
Michel Esper Neto ${ }^{1 *}$ (D) David W. Britt ${ }^{2}$ iD , Kyle Alan Jackson² ${ }^{\text {D }}$, Alessandro \\ Lucca Braccini $^{1}$ iD, Tadeu Takeyoshi Inoue ${ }^{1}$ (D) Marcelo Augusto Batista ${ }^{1}$ (iD
}

\begin{abstract}
Fertilizer formulation alternatives that avoid unnecessary losses and environmental impacts are being investigated in agricultural management. Seed priming with nanofertilizers prior to planting, reduces concerns about non-target dispersion; however, priming formulations and concentrations must be carefully selected to avoid undesired effects. Here, seed germination and seedling development were evaluated after seed priming with $\mathrm{CuO}$ nanoparticles (NPs), $\mathrm{CuO}$ bulk and $\mathrm{CuCl}_{2}$. The seeds were immersed in priming solutions of $0,20,40,80$ and $160 \mathrm{mg} . \mathrm{L}^{-1} \mathrm{Cu}$ for the three $\mathrm{Cu}$ sources. Following 8 hours priming, the seeds were evaluated for germination and vigor (first germination count). Root and shoot lengths were measured as well as shoot and root dry biomass. The copper NP did not show any toxic effects on corn seed germination and growth, and also promoted higher biomass when compared to the other $\mathrm{Cu}$ sources. On the other hand, $\mathrm{CuCl}_{2}$ primed seeds exhibited $\mathrm{Cu}$-toxicity in roots and shoots for all concentrations tested. Bulk Cu priming results indicated the better role of NPs size effects. These findings support NP-seed priming as an alternative to delivery of essential micronutrients, such as copper, to corn seedlings.
\end{abstract}

Index terms: nanofertilizer, phytotoxicity, characterization, $\mathrm{X}$-ray diffraction, transmission electron microscopy.

\section{Desenvolvimento inicial de plântulas de milho tratadas com nanofertilizante tenorita}

RESUMO: Alternativas para evitar perdas e impactos desnecessários no meio ambiente são alcançadas no manejo agrícola. A preparação de sementes com nanofertilizantes antes do plantio reduz as preocupações com a dispersão não-alvo; no entanto, formulações e concentrações devem ser cuidadosamente selecionadas para evitar efeitos indesejados. Aqui, avaliou-se a germinação e o desenvolvimento de plântulas após a iniciação das sementes com CuO NPs, CuO bulk e $\mathrm{CuCl}_{2}$. As sementes foram imersas em soluções primárias de $0,20,40$, 80 e $160 \mathrm{mg} \cdot \mathrm{L}^{-1}$ para as três fontes de Cu. Após 8 horas de preparação, as sementes foram avaliadas quanto à germinação e vigor (primeira contagem de germinação). Os comprimentos de raiz e parte aérea foram medidos, bem como a biomassa seca de parte aérea e de raízes. A fonte de nanopartículas de cobre não apresenta efeitos tóxicos no crescimento do milho e promove maior biomassa quando comparada às demais fontes. Por outro lado, fontes de $\mathrm{CuCl}_{2}$ mostraram alguns impactos negativos tóxicos nas raízes e parte aérea do milho para todas as doses testadas. Esses achados apoiam o tratamento de sementes com NPs como uma alternativa à entrega de micronutrientes essenciais, como o cobre.

Termos para indexação: nanofertilizante, fitotoxicidade, difração de raios-x, microscopia eletrônica de transmissão.
Journal of Seed Science, v.42, e202042040, 2020

http://dx.doi.org/10.1590/ 2317-1545v42240979 


\section{INTRODUCTION}

Nanotechnology is occupying a prominent evidence with new studies growing quickly in several science fields, including agriculture. In agriculture, nanoparticles (NPs) are commonly used as fertilizers or plant pathogen defenses. The greater advantages of nanofertilizers application is due the high reactivity, therefore enhanced nutrients bioavailability and bioactivity to plants, promoting improvements in structure, growth and development when compared to bulk size (Wang et al., 2016).

On the other hand, non-adjusted NPs higher concentration and application way can be negative to plants development and understand better NPs and plant interaction is need. NPs ability potential of passing the cell membrane is high due their general size between 1 to $100 \mathrm{~nm}$ (Adhikari et al., 2012) and generally, higher plants strong interact when exposure to NPs. Several metals are being studied as NPs form, among then copper (Cu). Keller et al. (2013) estimated that approximately 200 metric tons of $\mathrm{Cu} / \mathrm{Cu}$-oxides NPs were used worldwide in 2010 and these statistics will be increasing. Regarding plants applications, CuO NPs is less studied when compared to other NPs like ZnO which is the most studied. Despite of that, $\mathrm{CuO}$ effects seems to be flexible according to different crop plant species (Dimkpa et al., 2015).

Some reports show CuO NPs toxicity on germination, morphology, growth, transpiration and translocation in plant tissue (Rajput et al., 2018). These effects negative impacts are exhibited in some monocots, including wheat (Triticum aestivum) (Dimkpa et al., 2012), rice (Oryza sativa) (Shaw and Hossain, 2013), barley (Hordeum vulgare) (Shaw et al., 2014) and corn (Zea mays) (Wang et al., 2012). Those toxic effects, accumulation and NPs uptake will depend on the concentrations and exposure time. NPs phytotoxicity might variate due to differences in size and surface anatomy of seeds and plant species (Jain et al., 2017).

Cu NPs toxicity has been reported widely in various plant species, however studies showing these effects are under high concentrations exposure (>500 mg. $\mathrm{L}^{-1}$ ). At the same time, many positive reports are also available (Rajput et al., 2018). Regarding positive effects, there is evidence that CuO NPs act as a plant foliar fungicide with little or no deleterious effect on plant performance (Giannousi et al., 2013). Furthermore, CuO NPs promotes higher levels in photosynthetic rate when compared to soluble sources with $\mathrm{CuSO}_{4}$ (Nekrasova et al., 2011). Shah and Belozerova (2008) studying germination and development plants observed a significant effect of CuO NPs on root/shoot ratio, total $\mathrm{N}$ content and organic matter content. Therefore, CuO NPs application must be determined carefully, and criterial for sustainable must also be defined.

Corn is one of the most important crops in worldwide. The importance is in wide variety of industrial products, like cornstarch, corn oil, ethanol, besides serving as food source for animals and humans (Adhikari et al., 2015). These potential uses increase corn demand, and micronutrients like copper is required to enhance corn yield. Moreover, there is a challenge in coming decades to increase production without environmental impacts in a sustainable way (Liu and Lal, 2015). Cu plants deficiency normally occur due marginal soils expansion cultivation, using fertilizer without micronutrients, using less animal poultry in soils and new varieties nutrient demanding (Yamada, 2004).

Seed priming jointly nanoparticles may be a sustainable tool to nourish corn plants. Therefore, it was hypothesized that $\mathrm{Cu}$ sources, differing in solubility and size, present specific responses in corn seedlings development, when applied through seed priming. In addition, if there is a possibility of reducing Cu concentrations using CuO NP possible toxic effects of CuO NPs would also be greatly reduced. In this context, the specific aim was to investigate changes in the growth and development of corn seedlings after application of increasing concentrations of $\mathrm{Cu}$ as $\mathrm{CuO}$ NP, CuO bulk and soluble source copper chloride $\left(\mathrm{CuCl}_{2}\right)$ to be one of the first approximation to prime CuO NPs to corn.

\section{MATERIAL AND METHODS}

CuO NPs were made using $100 \mathrm{~mL}$ of $\mathrm{CuSO}_{4} .7 \mathrm{H}_{2} \mathrm{O} 0.1 \mathrm{~mol} . \mathrm{L}^{-1}$ and $100 \mathrm{~mL}$ of $0.4 \mathrm{~mol} . \mathrm{L}^{-1} \mathrm{NaOH}$. The solutions were prepared, and then slowly mixed in a $500 \mathrm{~mL}$ Erlenmeyer flask. After that, the solution was shaken vigorously on a 
magnetic stirrer at $1500 \mathrm{rpm}$ at room temperature $\left(22^{\circ} \mathrm{C}\right)$ for 15 minutes. The reaction flask was placed in a microwave for 2 minutes at a power of $700 \mathrm{~W}$. After formation of the black precipitate, the flask was centrifuged and washed several times with distilled water. The solution was frozen instantly using liquid nitrogen and dried by sublimation in a LS 3000 lyophilizer (Terroni ${ }^{\circ}$ ) and packed in a vacuum glass desiccator, protected from light.

The CuO powder was analyzed by X-ray diffraction in an XRD 6000 system (Shimadzu ${ }^{\circ}$, Kyoto, Japan). Diffractograms were obtained between 20 to $75^{\circ} 2 \theta$, in intervals of $0.02^{\circ} 2 \theta$ for 0.6 seconds step-mode, using CoK $\alpha$ radiation and nickel filter tenorite (CuO) (Figure 1).

The size of the particles was determined by transmission electron microscopy (TEM, CM200, Philips ${ }^{\circ}$, Amsterdam, Netherlands). TEM samples were prepared by depositing volume of a $\mathrm{CuO}$ in water suspension onto carbon grids coated with copper grids. Synthetic CuO NP used in this assay had a needle shape (Figure 2). The average diameter was 139.1 nanometers measured by Dynamic Scattered Light (DLS) (Figure 3).

The seeds analyzed here was the hybrid IAC 8046. The selected seeds had the same size. The seeds were disinfected with sodium hypochlorite solution ( $1 \% \mathrm{v} / \mathrm{v})$ for 2 minutes and then washed seven times with ultrapure water. Before the experiment installation, seeds were kept in a dry and dark place at a temperature of $16{ }^{\circ} \mathrm{C}$ to avoid changes in seed physiology.

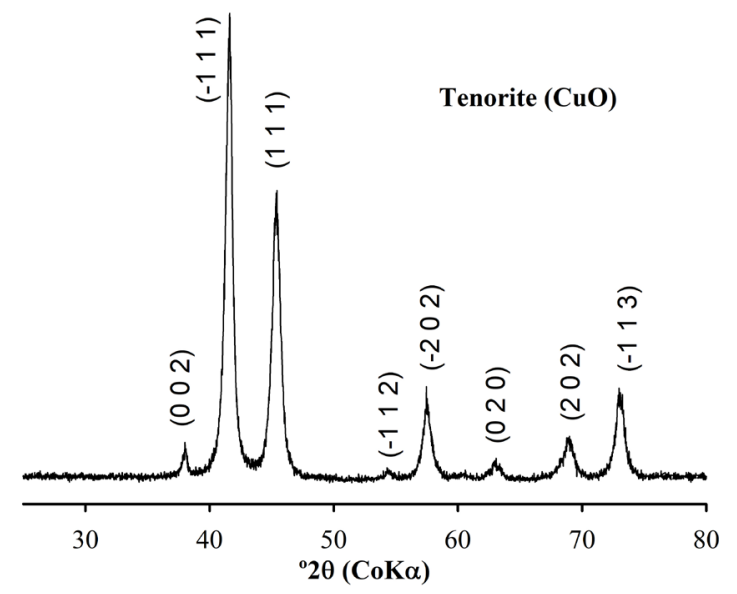

Figure 1. X-ray diffraction of CuO nanoparticles (Tenorite-CuO NP).

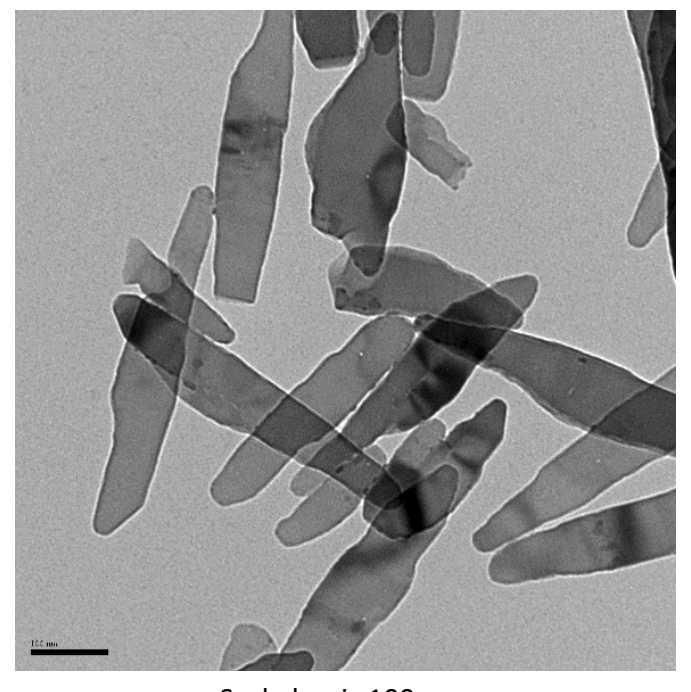

Scale bar is $100 \mathrm{~nm}$.

Figure 2. TEM image of nanoparticle (Tenorite-CuO NP). 


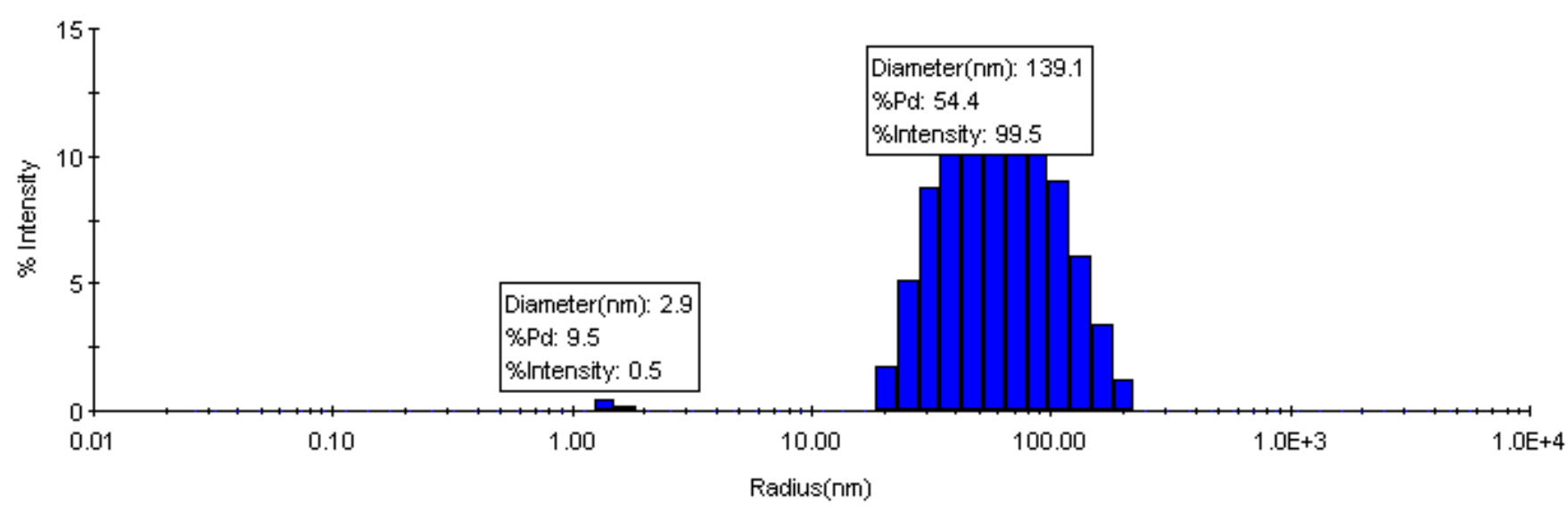

Figure 3. DLS histogram of nanoparticle (Tenorite-CuO NP).

To evaluate the effects of $\mathrm{Cu}$ sources application in corn, a cross-factor experiment $(5 \times 3)$ was carried out in a completely randomized design with four replicates. The five-level factor was concentrations $\left(0,20,40,80\right.$ and $\left.160 \mathrm{mg} . \mathrm{L}^{-1}\right)$ concentrations based on $\mathrm{Cu}$ content and the factor with three levels were the different sources ( $\mathrm{CuO} \mathrm{NP}, \mathrm{CuCl}_{2}$, and $\mathrm{CuO}$ bulk). Each plot was composed of 50 seeds that were immersed in the different solutions/suspensions containing a total volume of $200 \mathrm{~mL}$ with different $\mathrm{Cu}$ concentrations for $8 \mathrm{~h}$, and then dried at room temperature $25^{\circ} \mathrm{C}$ for one hour.

The Cu NPs were compared with two other Cu sources. The first was a $\mathrm{Cu}$ ionic solution, which was prepared by dissolving $\mathrm{CuCl}_{2}$ purchased from Sigma Aldrich Chemical $\mathrm{Co}$ in ultrapure water, the second one was CuO bulk with nonnanometric (> $300 \mathrm{~nm}$ ). The insoluble sources (Synthetic CuO NP and CuO bulk) were suspended directly in ultrapure water and dispersed using an ultrasonic vibration shaker (100 kHz for five minutes).

Seed germination was assessed using Germitest paper. The seeds were placed in three sheets moistened with ultrapure water equivalent to 2.5 times the dry biomass of the paper and each seed was one cm or more away from another seed. The rolls were prepared and taken to the Mangelsdorf germination chamber set at a constant temperature of $25^{\circ} \mathrm{C}$ for a period of 8 days. The results were expressed as percentage of normal, abnormal and non-viable seedlings (Brasil, 2009). The vigor test was performed on the fifth day, first germination count (Brasil, 2009).

After the germination test, the root length (distance in $\mathrm{cm}$ from the stem base to the root tip) and shoot length (distance in $\mathrm{cm}$ from the base of the leaf to the tip of the leaf) were measured in 15 seedlings randomly selected with the aid of a millimeter ruler. Then, the seedlings were transferred to Kraft paper bags and weighed to obtain the fresh biomass production, later these same seedlings were taken to a drying oven at a constant temperature of $60{ }^{\circ} \mathrm{C}$ for 72 $\mathrm{h}$ to measure the dry biomass.

The data of all the variables were submitted to normality of errors and homoscedasticity of variances tests $(p>$ 0.01). The different concentrations and sources and interactions were tested by F test. Interaction was partitioned only for concentrations within each source. Quantitative data "concentrations" were analyzed regression. The qualitative data "sources" were analyzed by Tukey test, $5 \%$ probability was used $(p<0.05)(Z i m m e r m a n n, 2014)$.

\section{RESULTS AND DISCUSSION}

The results obtained after concentration partitioning within each tested $\mathrm{Cu}$ sources ( $\mathrm{CuO}$ NPs, $\mathrm{CuO}$ bulk and $\mathrm{CuCl}_{2}$ ) for germination, vigor, dead seed and abnormal seedlings are shown in Figure 4. None statistical differences were found for germination, vigor, dead seeds and abnormal seedlings as well $(p>0.05)$. The general averages for germination seeds were $84.8,82.5$ and $81.2 \%$ for the $\mathrm{CuCl}_{2}, \mathrm{CuO}$ bulk and $\mathrm{CuO}$ NPs, respectively (Figure 4A). In relation to vigor 
seeds, the averages were 79.1, 74.5 and $74.3 \%$ for $\mathrm{CuCl}_{2}, \mathrm{CuO}$ bulk and $\mathrm{CuO}$ NPs, respectively (Figure 4B). For dead seeds the averages were 11.0, 10.4 and 9.5 for $\mathrm{CuCl}_{2}, \mathrm{CuO} \mathrm{NP}$, and $\mathrm{CuO}$ Bulk, respectively (Figure 4D). Abnormal seeds averages obtained was 7.3, 6.1 and 5.3\%, for $\mathrm{CuCl}_{2}$, $\mathrm{CuO} \mathrm{NPs,} \mathrm{and} \mathrm{CuO}$ Bulk, respectively (Figure 4D).

Figure 5 show the effects of the $\mathrm{Cu}$ doses for each source tested for the assessment, shoot length, radicle length, and shoot length/radicle length ratio. Shoot length results are showed in Figure 5A. The doses affected significantly seedlings shoot length for $\mathrm{CuCl}_{2}$ source. Each mg. $\mathrm{L}^{-1}$ increased in seed priming solution $\left(\mathrm{CuCl}_{2}\right)$ decreased $0.05 \mathrm{~cm}$ the root length. It was also significant differences among sources tested, that means there was root growth inhibition when applied $\mathrm{CuCl}_{2}(7.87 \mathrm{~cm})$, compared to the other sources $\mathrm{CuO}$ NPs $(10.2 \mathrm{~cm})$, and CuO Bulk $(10.8 \mathrm{~cm})$.

Root length had similar behavior than shoot length. $\mathrm{CuCl}_{2}$ source decrease significantly seedlings root length (Figure $5 B$ ). It was decreased $0.02 \mathrm{~cm}$ in shoot length for each mg. $\mathrm{L}^{-1}$ concentration increased. In addition, considering the average concentration, shoot growth inhibition was higher when applied $\mathrm{CuCl}_{2}(7.4 \mathrm{~cm})$, compared to the other sources CuO NPs $(9.4 \mathrm{~cm})$, and CuO Bulk $(8.9 \mathrm{~cm})$.

Shoot length/root length ratio (Figure $5 \mathrm{C}$ ), was altered by doses tested just $\mathrm{CuCl}_{2}$. It was adjusted positive linear regression dose-response, where each mg. $\mathrm{L}^{-1}$ increased in seed priming solution decreased $0.012 \mathrm{~cm} . \mathrm{cm}^{-1}$ the shoot length/root length ratio. Beside of that, regardless doses tested, it was evident differences among sources tested, that means shoot length/root length ratio was higher when applied $\mathrm{CuCl}_{2}$ source $\left(1.26 \mathrm{~cm} . \mathrm{cm}^{-1}\right)$, compared to the other sources CuO NPs $\left(0.89 \mathrm{~cm} . \mathrm{cm}^{-1}\right)$, and CuO Bulk $\left(0.87 \mathrm{~cm} . \mathrm{cm}^{-1}\right)$.
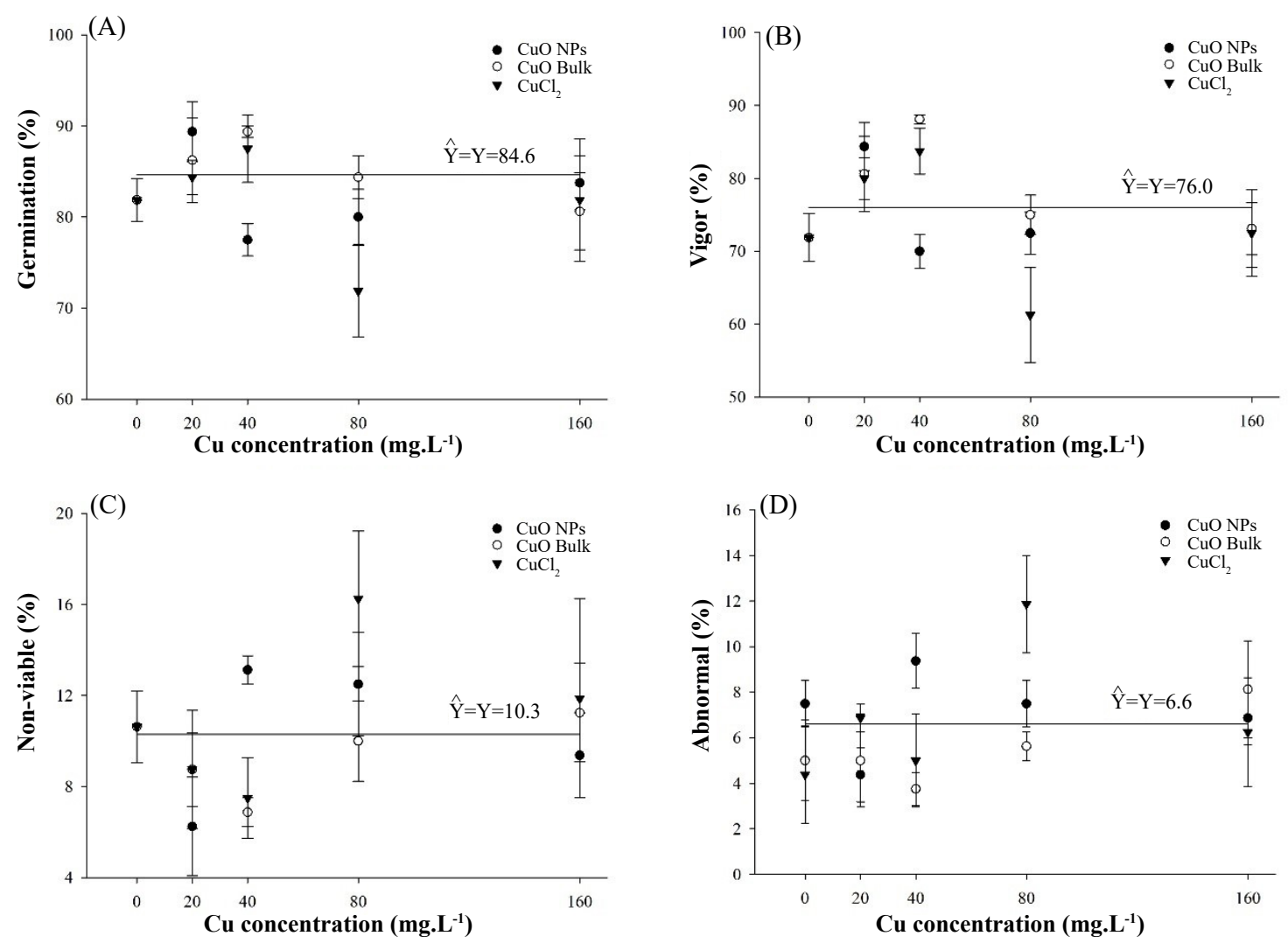

Figure 4. (A) Seed germination, (B) seed vigor, (C) dead seed, and (D) abnormal seed of corn after application of different concentration and sources of $\mathrm{Cu}$. 

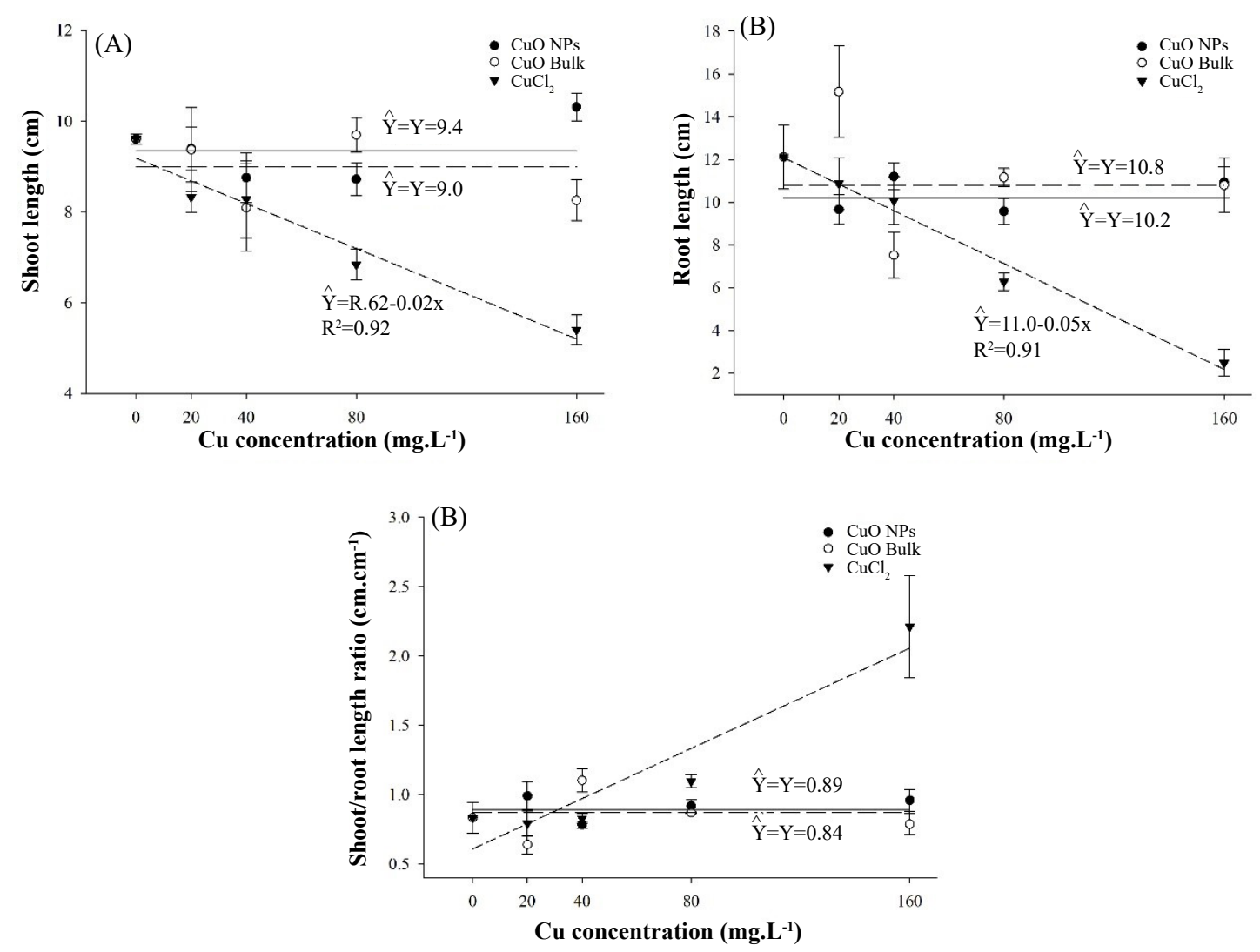

Figure 5. (A) Shoot length, (B) root length, (C) shoot length/root length ratio corn after different concentration and sources of $\mathrm{Cu}$.

Figure 6 show the effects of $\mathrm{Cu}$ concentration for each source tested for evaluated mass variables. The concentration affected significantly seedling shoot mass only for $\mathrm{CuCl}_{2}$ (Figure 6A). The maximum shoot dry mass observed ( $0.32 \mathrm{~g}$ ) was obtained at $95.9 \mathrm{mg} . \mathrm{L}^{-1}$. Nevertheless, it was evident that shoot mass decrease in higher doses, since for the higher dose tested $160 \mathrm{mg} \cdot \mathrm{L}^{-1}$ the mass was $0.28 \mathrm{~g}$ that is a reduction of almost of $14 \%$. CuO bulk, and CuO NPs was not altered by the treatments, and the averages were 0.28 and $0.24 \mathrm{~g}$, respectively. Regarding root dry mass (Figure 6B), CuO NPs promotes twice root dry mass than $\mathrm{CuCl}_{2}$ source, that means $100 \%$ more roots. Shoot mass/root mass ratio (Figure $6 \mathrm{C}$ ), was not altered by doses tested, although compared just the sources in doses averages, differences were also significant. $\mathrm{FeCl}_{2}$ obtained higher ratio $\left(3.7 \mathrm{~g} . \mathrm{g}^{-1}\right)$ than CuO bulk $\left(2.7 \mathrm{~g}^{\mathrm{g}} \mathrm{g}^{-1}\right)$ that in turn obtained higher ratio than Cu NPs $\left(2.3 \mathrm{~g} . \mathrm{g}^{-1}\right)$.

No effects in germination were observed. It was shown that all assessments linked to germination percentage were not significantly different among all the treatments $(p<0.05)$. This result may be due seed coat which plays a very important role in protecting the embryo from external factors and have selective permeability. NPs may not affect germination if they cannot pass through seed coats (Lin and Xing, 2008). Stampoulis et al. (2009) also observed that seed germination is generally an insensitive measure of effects from NPs. Moreover, other factor could also contributes for the lack of responses in germination assessment like the relatively short exposure of NPs from seed, or other uncharacterized biological processes (Wang et al., 2012).

Cu NPs doses applications resulted in a non-significantly effects of root length, shoot length or root length/shoot length ratio. Otherwise, it was shown negatives impacts of soluble source $\mathrm{CuCl}_{2}$ for root and shoot length, root elongation of sensitive plant species would have a dose-dependent response (Lin and Xing, 2008), normally roots are the first plant tissue to confront with excess concentrations and then toxic symptoms seem to appear more in roots rather than in shoots (Sresty and Rao, 1999). In our study, this fact agrees, despite shoot and root had decreased according 
to growing doses of $\mathrm{CuCl}_{2}$, apparently root grow was much more negatively affected than shoot. Such higher toxicity might be explained by the fully dissolution to the free ions $\mathrm{Cu}^{2+}$ and $\mathrm{Cl}$ in high concentration in solution. Other reason on negative root length is since after penetration of the seed coats, the emerging radicles rapidly absorb nutrients and water, therefore maximizing exposure to toxicity.

The shoot biomasses of plants exposed to $\mathrm{Cu}$ NP or CuO bulk were not significantly different. Although $\mathrm{CuCl}_{2}$ promoted more shoot mass until determined point. Higher concentrations also decreased shoot mass. In adequate amounts $\mathrm{Cu}$ acts in the process of photosynthesis being one of the constituents of plastocyanin that is important in electron transport between photosystems II and I (Batista et al., 2018). Regarding root biomass CuO NPs showed better results than the other sources. Although there no dose significance. This results differ from those from (Wang et al., 2012) which find that CuO NPs reduced the corn weight of root and shoot tissues by $60 \%$ and $34 \%$ respectively, compared to the unexposed control plants. On the other hand (Adhikari et al., 2015) found dry matter corn mass of shoot and root was higher through CuO NPs source. The main differences among these studies were concentration, the first one, negatives NPs impacts were realized at $100 \mathrm{mg} \cdot \mathrm{L}^{-1}$, the second one beneficial effect were noticed 0.5 $\mathrm{mg} . \mathrm{L}^{-1}$. Our experimental results do not prove any toxic effects of CuO NPs on plant growth even in $160 \mathrm{mg} \cdot \mathrm{L}^{-1} \mathrm{corn}$ seed priming, on the contrary, even on doses average, CuO NPs promotes higher biomass than the other sources. Despite of that, CuO NPs seems to not alter shoot mass/root mass normal development, since after seed germination, plants generally contribute the major portion of the metabolites towards root expansion (Adhikari et al., 2015). In addition, further studies are needed on the durability of this unique Cu NPs response at the later phase of corn plant growth, and more studies need to be done to clarify the ecotoxicological effects $\mathrm{CuCl}_{2}$ risk.
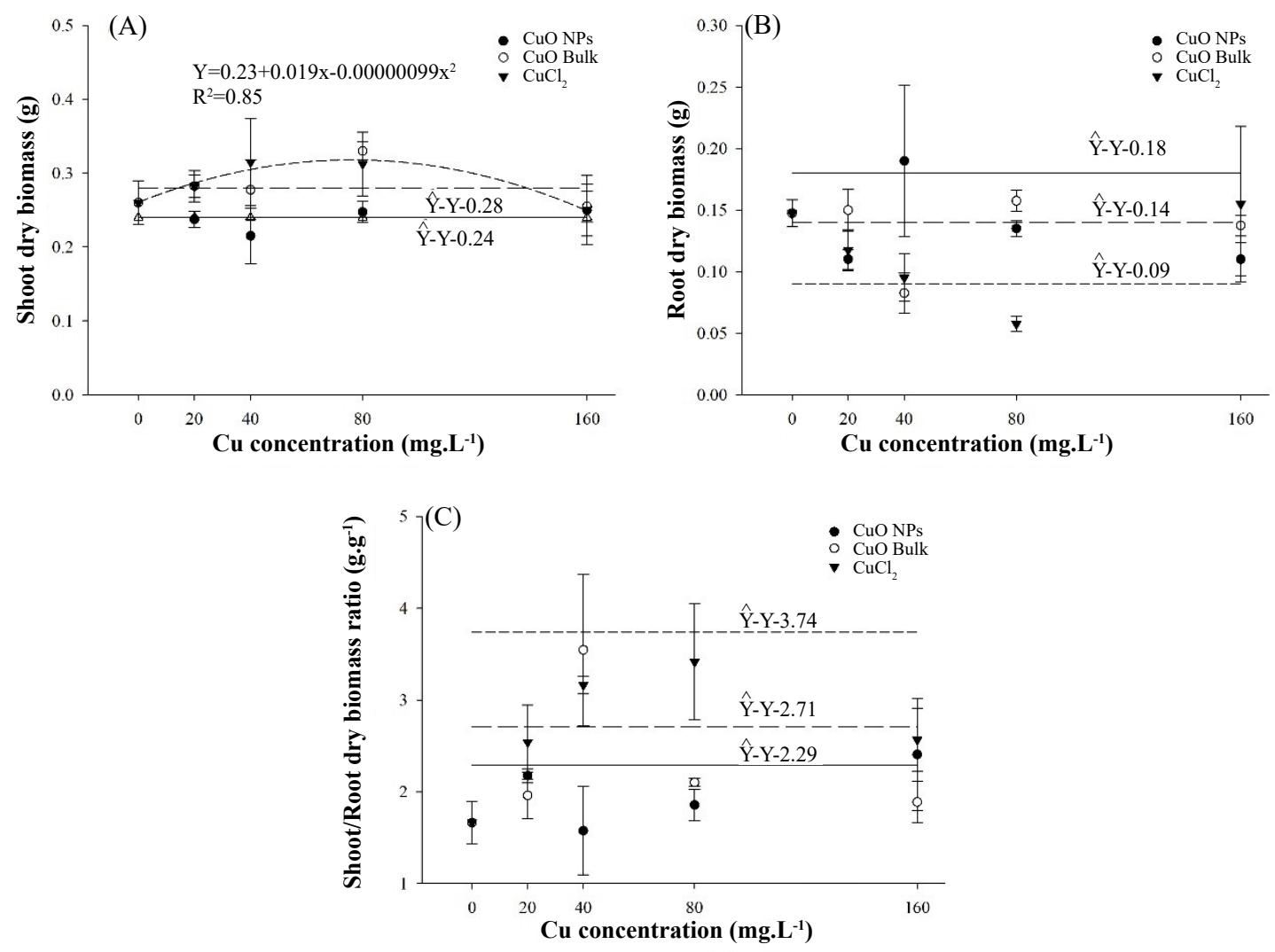

Figure 6. (A) Shoot mass, (B) root mass, (C) Shoot mass/root mass ratio of corn after different rates application and sources of $\mathrm{Cu}$. 


\section{CONCLUSIONS}

The results indicate that there is possible to synthesize Cu NPs in easy way and apply in corn plants as a seed priming. $\mathrm{CuO}$ NPs seems to be a better source than $\mathrm{CuO}$ bulk and $\mathrm{CuCl}_{2}$ to prime corn seeds, in addition, there is evidence of potential risk of $\mathrm{CuCl}_{2}$ seed priming mainly in high concentration.

No toxic effects were noticed during the seedling development regarding CuO NPs.

\section{REFERENCES}

ADHIKARI, T.; KUNDU, S.; BISWAS, A.K.; TARAFDAR, J.C.; RAO, A.S. Characterization of zinc oxide nano particles and its effect on growth of maize (Zea mays L.) plant. Journal of Plant Nutrition, v.38, n.10, p.1505-1515, 2015. https://doi.org/10.1080/01904167.2014.992536

ADHIKARI, T.; KUNDU, S.; BISWAS, A.K.; TARAFDAR, J.C; RAO, A.S. Effect of copper oxide nano particle on seed germination of selected crops. Journal of Agricultural Science and Technology, v.2, n.6, p.815-823, 2012. https://www.researchgate.net/ profile/J_Tarafdar/publication/262178472_Effect_of_Copper_Oxide_Nano_Particle_on_Seed_Germination_of_Selected_Crops/ links/0f317536ceb9bf210e000000.pdf

BATISTA, M.A.; INOUE, T.T.; ESPER-NETO, M.; MUNIZ, A.S. Princípios de fertilidade do solo, adubação e nutrição mineral. In: BRANDÃO-FILHO, J.U.T.; FREITAS, P.S.L.; BERIAN, L.O.S.; GOTO, R. Hortaliças-fruto. Maringá: EDUEM, 2018. p.113-161.

BRASIL. Ministério da Agricultura, Pecuária e Abastecimento. Regras para análise de sementes. Ministério da Agricultura, Pecuária e Abastecimento. Secretaria de Defesa Agropecuária. Brasília: MAPA/ACS, 2009. 395p. https:// www.agricultura.gov.br/arq_editor/ file/2946_regras_analise_sementes.pdf

DIMKPA, C.O.; MCLEAN, J.E.; BRITT, D.W.; ANDERSON, A.J. Nano-CUO and interaction with nano-ZnO or soil bacterium provide evidence for the interference of nanoparticles in metal nutrition of plants. Ecotoxicology, v.24, n.1, p.119-129, 2015. https://doi. org/10.1007/s10646-014-1364-x

DIMKPA, C.O.; MCLEAN, J.E.; LATTA, D.E.; MANANGÓN, E.; BRITT, D.W.; JOHNSON, W.P.; BOYANOV, M.I.; ANDERSON. A.J. CUO and ZnO nanoparticles: phytotoxicity, metal speciation, and induction of oxidative stress in sand-grown wheat. Journal of Nanoparticle Research, v.14, n.9, p.1-15, 2012. https://doi.org/10.1007/s11051-012-1125-9

GIANNOUSI, K.; AVRAMIDISB, I.; DENDRINOU-SAMARA, C. Synthesis, characterization and evaluation of copper based nanoparticles as agrochemicals against Phytophthora Infestans. RSC Advances, v.3, n.44, p.21743-21752, 2013. https://doi.org/10.1039/ C3RA42118J

JAIN, N.; BHARGAVA, A.; PAREEK, V.; AKHTAR, S.M.; PANWAR, J. Does seed size and surface anatomy play role in combating phytotoxicity of nanoparticles? Ecotoxicology, v.26, n.2, p.238-249, 2017. https://doi.org/10.1007/s10646-017-1758-7

KELLER, A.A.; MCFERRAN, S.; LAZAREVA, A.; SUH, S. Global life cycle releases of engineered nanomaterials. Journal of Nanoparticle Research, v.15, n.6, p.1-17, 2013. https://doi.org/10.1007/s11051-013-1692-4

LIN, D.; XING, B. Root uptake and phytotoxicity of ZnO nanoparticles. Enviromental Science Technololgy, v.42, n.15, p.5580-5585, 2008. https://doi.org/10.1021/es800422x

LIU, R.; LAL, R. Potentials of engineered nanoparticles as fertilizers for increasing agronomic productions. Science of Total Environment, v.514, p.131-139, 2015. https://www.sciencedirect.com/science/article/pii/S0048969715001266

NEKRASOVA, G.F.; USHAKOVA, O.S.; BERMAKOV, A.E.; UIMIN, M.A.; BYZOV, I.V. Effects of copper (II) ions and copper oxide nanoparticles on Elodea densa. Russian Journal of Ecology, v.42, n.6, p.422-428, 2011. https://doi.org/10.1134/S1067413611060117

RAJPUT, V.D.; MINKINA, T.; SUSKOVA, S.; MANDZHIEVA, S.; TSITSUASHVILI, V.; CHAPLIGIN, V.; FEDORENKO, A. Effects of copper nanoparticles (CuO NPs) on crop plants: a mini review. Bionanoscience, v.8, n.1, p.36-42, 2018. https://doi.org/10.1007/s12668017-0466-3

SHAH, V.; BELOZEROVA, I. Influence of metal nanoparticles on the soil microbial community and germination of lettuce seeds. Water Air Soil Pollution, v.197, n.1, p.143-148, 2008. https://doi.org/10.1007/s11270-008-9797-6 
SHAW, A.K.; GHOSH, S.; KALAJI, H.M.; BOSA, K.; BRESTIC, M.; ZIVCAK, M.; HOSSAIN, Z. Nano-CuO stress induced modulation of antioxidative defense and photosynthetic performance of Syrian barley (Hordeum vulgare L .). Environmental Experimental Botany. v.102, n.1, p.37-47, 2014. https://doi.org/10.1016/j.envexpbot.2014.02.016

SHAW, A.K.; HOSSAIN, Z. Chemosphere Impact of nano-CuO stress on rice (Oryza sativa L.) seedlings. Chemosphere, v.93, n.6, p.906-915, 2013. https://doi.org/10.1016/j.chemosphere.2013.05.044

SRESTY, T.V.S.; RAO, K.V.M. Ultrastructural alterations in response to zinc and nickel stress in the root cells of pigeonpea. Environmental Experimental Botany, v.41, n.1, p.3-13, 1999. https://doi.org/10.1016/S0098-8472(98)00034-3

STAMPOULIS, D.; SINHA, S.K.; WHITE, J.C. Assay-dependent phytotoxicity of nanoparticles to plants. Enviromental Science Technology, v.43, n.24, p.9473-9479, 2009. https://doi.org/10.1021/es901695c

WANG, P.; LOMBI, E.; ZHAO, F.; KOPITTKE, P.M. Nanotechnology: a new opportunity in plant sciences. Trends Plant Science, v.21, n.8, p.699-712, 2016. https://doi.org/10.1016/j.tplants.2016.04.005

WANG, Z.; XIE, X.; ZHAO, J.; LIU, X.; FENG, W.; WHITE, J.C.; XING, B. Xylem- and phloem-based transport of CuO nanoparticles in maize (Zea mays L.). Enviromental Science Technology, v.46, n.8, p.4434-4441, 2012. https://doi.org/10.1021/es204212z

YAMADA, T. Deficiências de micronutrientes, ocorrência, detecção e correção: o sucesso da experiência brasileira. Informações Agronômicas, n.105, p.1-12, 2004. https://www.agencia.cnptia.embrapa.br/Repositorio/Encarte105_000fxf2r0tv02wyiv80soht9hi492vm1.pdf

ZIMMERMANN, F.J.P. Estatística aplicada à pesquisa agrícola. 2 ed. Santo Antônio de Goiás: Embrapa Arroz e Feijão, 2014. 402p. use, distribution, and reproduction in any medium, provided the original work is properly cited. 